\title{
LESSONS LEARNED AFTER DISASTER? EMERGENCY SHELTER AND HOUSING POLICY AFTER HURRICANE KATRINA
}

\author{
TANYA BUHLER CORBIN \\ Department of Political Science, Radford University, USA
}

\begin{abstract}
There is a commonly held assumption that governmental leaders "learn lessons" after disasters. The "lessons learned" narrative was particularly pervasive after Hurricane Katrina, which was widely understood as a failure in governmental preparedness and response. If governmental leaders learned lessons after disaster, we would expect to find changes in policies that reflect these lessons. This study examines the changes in emergency shelter planning and housing policy at the federal level after Hurricane Katrina. To determine whether policy learning occurred, I employ content analysis to identify the emergency shelter and post-disaster housing recommendations outlined in the government investigative reports from the congressional and executive branches. I compare the recommendations in the investigative committee reports with the legislative changes enacted in the Post Katrina Emergency Management Reform Act of 2006. Results indicate that the recommendations and findings of the congressional and executive branch investigations were incorporated into legislative changes. Thus, there is evidence that policy learning occurred in the wake of Hurricane Katrina.

Keywords: policy change, policy learning, disaster, housing, Hurricane Katrina, Congress, legislation.
\end{abstract}

\section{INTRODUCTION}

Conventional wisdom is that after a major disaster, government leaders "learn lessons" from the event, and that these lessons translate into policy changes that will create improvements in disaster management. The idea that there are "lessons learned" after disasters is a powerful and pervasive narrative, as elected officials have an incentive to appear responsive to their constituents and ensure their electoral success. The narrative of "lessons learned" was particularly pervasive after Hurricane Katrina, which was widely understood as a failure in governmental preparedness and response. So powerful is the "lessons learned" narrative that the White House report investigating Hurricane Katrina includes "lessons learned" in the title, as well as an entire chapter in the report devoted to the topic [1]. Likewise, the congressional report from the Select Bipartisan Committee to Investigate the Preparation for and Response to Hurricane Katrina (Select Committee) employs the lessons learned framework [2].

Despite the normative assumption that government leaders learn lessons after disaster, there is nothing inherent about disasters that ensures leaders will learn lessons, and no guarantee that policy changes will be enacted based on the lessons learned. Rather, the disaster presents the potential for policy change and policy learning [3]. Disasters create "windows of opportunities" for policy innovation and reform, particularly if new participants are successful in gaining access to policy makers [4]. However, numerous factors determine whether policy learning and policy change occur, including the type of disaster at issue. Prior research has found policy change and policy learning at the federal level have been less frequently occurring after hurricanes compared to other disaster types (e.g. earthquakes or aviation security) [3].

Hurricane Katrina provides a unique opportunity to examine the normative assumption that government leaders learned lessons after the disaster. If government leaders learn from the failures of Hurricane Katrina, we can expect to see evidence of learning in post-disaster 
assessments and reports, as well as in legislative changes. This study examines the ways in which congressional leaders and the executive branch investigated the failures in governmental preparedness and response after Hurricane Katrina, and whether and to what extent they incorporated these lessons into legislative policy changes. This study focuses specifically on the changes in emergency shelter planning and post-disaster housing support for the region affected by Hurricane Katrina, as these were the areas in which governmental response was most heavily criticized by the media. I employ content analysis to identify emergency shelter and post-disaster housing policy recommendations outlined in investigative reports from the congressional and executive branches. Next, I compare the recommendations in the investigative committee reports with the legislative changes enacted in the Post Katrina Emergency Management Reform Act of 2006. This Act is the predominant legislation enacted in response to the congressional and executive investigations after Hurricane Katrina, and it enacts significant changes to governmental agencies' approaches to disasters. I conclude with a discussion of the results and the implications for future research.

\section{THEORETICAL GROUNDING AND RESEARCH QUESTION}

\subsection{Focusing events, policy learning, and policy change after disaster}

Disasters and crises can act as catalysts for drastic and rapid policy changes by elucidating policy failures and opening agenda space for policy advocates to advance new proposals. These 'focusing events' capture the attention of policymakers, and force them to take action to remedy a problem. Focusing events are virtually impossible to keep off the policy agenda because of the media attention and public interest they generate. They create the possibility for blame attribution in disasters, crises, and other failures, and provide an opportunity for new policy proposals, and rapid, non-incremental policy change [5], [6]. In the wake of a large disaster or catastrophe, the powerful symbolism of the event, coupled with the accompanying attention by media, public, and legislators, creates a unique opportunity for legislative policy change [4], [7], [8].

Although disasters create opportunities for policy change, there is wide variance as to the extent of policy change that is likely to occur after an event. That is, a crisis or disaster may create agenda space for new proposals, but these proposals do not necessarily result in policy learning or policy changes that improve disaster management. Birkland [7] found that legislative action after hurricanes tended to take on the form of distributive politics, with Congress allocating funds to rebuild, rather than changing policies to improve disaster preparedness and response. However, Hurricane Katrina provides a unique opportunity for policy makers to adopt policy changes and to engage in policy learning. Major events and disasters that are largest in scope and scale present the greatest potential for policy change, because they illustrate policy failures in government [7].

The perceived failures of the governmental preparedness for and response to Hurricane Katrina created a significant opportunity for policy change and policy learning. An important question is whether the policy recommendations offered in the wake of disasters translate into policy changes, and more importantly, policy learning. Building on May's [9] criteria for evidence of policy learning, Birkland [3] has developed a model of event-related policy change and learning. In this model, examples of evidence of learning in Congress include changes in the topics of debate, content in hearings and reports, and legislative changes. Policy change can occur after an event without policy learning, particularly if lawmakers are pressured to "do something" to address governmental failures after an event. Thus, to assess 
whether actual policy learning occurred, rather than policy action, a contextual analysis is essential. In addition to examining legislative changes, to find evidence of learning, analyzing documents detailing debates and investigations is an important component in evaluating learning. Examples of such documents include congressional hearings and committee reports, executive branch reports, and agency documents and reports.

\subsection{Research questions}

Based on the theories of event related learning, if policy learning has occurred, we would expect to see policy changes recommended and adopted into legislation. Thus, the research questions for this study seek to identify evidence of policy learning by asking the following questions: What policy recommendations for emergency shelter and housing policy changes did the congressional and executive committees make in their investigative reports? Which, if any, of the recommended policy changes in emergency shelter and housing policy were enacted into legislation after Hurricane Katrina?

\section{METHODS}

This research focuses on the U.S. Congress, which, by institutional design, functions as the primary governmental institution with oversight functions for agencies who respond to disasters. Although disaster response occurs in conjunction with state and local level agencies and organizations, the decisions about plans and priorities upon which many state, local, and community organizations are dependent are made at the congressional level. Congress is an institution that responds to catastrophic events. Members are accountable to their constituents; they want constituents to perceive them as responsive to governmental problems. This project examines emergency shelter and temporary housing policy changes after Hurricane Katrina. This aspect of the governmental response received the most severe criticism from media, survivors, and the American public. The federal government agencies are tasked with disaster response, particularly the Federal Emergency Management Agency (FEMA) and the United States Department of Housing and Urban Development (HUD). Emergency shelter and housing are crucial components to any successful disaster management, and thus are important response aspects to study.

To determine whether policy learning occurred, I first conducted a discourse analysis to evaluate the reports issued from the governmental investigations of the response to Hurricane Katrina. Congress and the President were compelled to investigate the governmental response to Hurricane Katrina in light of abject failures, and offered assessments and recommendations based on their investigations in the reports they issued. Using the recommendations from Congress and the Executive branch related to shelter and housing, I compare these with the legislation enacted to determine which recommendations were incorporated. The primary legislation enacted after Hurricane Katrina was the Post Katrina Emergency Management Reform Act of 2006 (PKEMRA), which reformed FEMA and fundamentally revised the governmental approach to disasters.

Conducting a discourse analysis of the congressional and executive branch investigations after Hurricane Katrina reveals whether there is policy learning, rather than merely policy change. The investigations were extensive, spanning several months, and involved hearings and interviews with all stakeholders affected by Hurricane Katrina. The recommendations contained in the reports incorporate diverse perspectives from all affected stakeholders. Comparing this with the legislative changes in the PKEMRA Act of 2006 reveals which of the recommendations were ultimately incorporated into the legislative policy changes. Although there can still be policy learning occurring in the investigations that is not 
incorporated into the legislation, the legislative changes provide a clear link between the learning and the implementation of this learning into policy changes.

\section{RESULTS AND DISCUSSION}

\subsection{White House report recommendations}

The White House convened a task force to review the federal response to Hurricane Katrina. They issued the final report, The Federal Response to Hurricane Katrina: Lessons Learned, on February 23, 2006. The task force included White House senior staffers as well as the cabinet heads. The report included a chapter devoted to "lessons learned," which outlined seventeen critical federal challenges related to the disaster preparation and response, and an appendix detailing 125 specific policy recommendations. One of the critical challenges identified in the report is mass care and housing. The report presents the following "lesson learned" related to this challenge: "Using established Federal core competencies and all available resources, the Department of Housing and Urban Development, in coordination with other departments of the Executive Branch with housing stock, should develop integrated plans and bolstered capabilities for the temporary and long-term housing of evacuees. The American Red Cross and the Department of Homeland Security should retain responsibility and improve the process of mass care and sheltering during disasters" [1]. Table 1 outlines the mass care and housing recommendations in the report.

Table 1: $\quad$ Selected recommendations for mass care and housing. (Source: White House, 2005.)

\begin{tabular}{|l|l|}
\hline Recommendation & Rationale for recommendation \\
\hline $\begin{array}{l}\text { ARC (American Red Cross) and } \\
\text { DHS (Department of Homeland } \\
\text { cecurity) should retain the mass } \\
\text { during disasters. }\end{array}$ & $\begin{array}{l}\text { ARC has extensive experience providing mass care and shelters during } \\
\text { disasters, but their status as a non-government organization limits their } \\
\text { access to federal planning meetings. DHS and ARC should strengthen } \\
\text { their planning and operational relationships with HUD (Housing and } \\
\text { Urban Development). HUD, DHS and ARC must develop a close } \\
\text { working relationship. During non-emergency times, they must jointly } \\
\text { plan for mass care and housing during disasters, train and conduct } \\
\text { exercises. }\end{array}$ \\
\hline $\begin{array}{l}\text { Fesignate HUD as the lead } \\
\text { Federal agency for the provision } \\
\text { DHS). }\end{array}$ & $\begin{array}{l}\text { HUD, with extensive experience providing housing resources for those in } \\
\text { need, must use its extensive network of regional offices and State and } \\
\text { local housing agencies, to prepare for potential relocation emergencies. } \\
\text { Trailers should not be the default temporary housing offered to all } \\
\text { evacuees leaving shelters. HUD, rather than DHS, should be the lead } \\
\text { agency for housing and should devote resources to gain this competency } \\
\text { with support from ARC, and other agencies. HUD must augment its } \\
\text { current housing capacity in order to create the ability to arrange housing } \\
\text { for disaster victims and adequately train, exercise and resource this } \\
\text { capability. DHS should retain its vital coordinating function for the entire } \\
\text { disaster response. }\end{array}$ \\
\hline $\begin{array}{l}\text { Assist States and municipalities in } \\
\text { developing mass relocation plans } \\
\text { for each major metropolitan area } \\
\text { and inventories of existing } \\
\text { shelters and shelter sites. }\end{array}$ & $\begin{array}{l}\text { Plans must match mass evacuation plans developed for metropolitan } \\
\text { areas and should include the pre-identification of sites suitable for the } \\
\text { establishment of shelters. Plans should include guidelines regarding } \\
\text { suitable shelters and thorough inventories of shelters already in existence. } \\
\text { HUD should take the lead role in relocation planning and inventorying } \\
\text { shelters, with DOT, DOI and USDA assuming supporting roles. HUD } \\
\text { can combine data from Federal, State, and local sources to compile } \\
\text { inventories and establish the frequency of inventory updates. }\end{array}$ \\
\hline
\end{tabular}


Table 1: Continued.

\begin{tabular}{|c|c|}
\hline Recommendation & Rationale for recommendation \\
\hline $\begin{array}{l}\text { DHS should develop a system to } \\
\text { maintain awareness of the } \\
\text { movement of shelter and } \\
\text { temporary housing residents }\end{array}$ & $\begin{array}{l}\text { Local, State, and Federal officials in charge of sheltering evacuees must } \\
\text { know the number and type (e.g. number of disabled, number of minors) of } \\
\text { evacuees, names and personal identifying data as they move between } \\
\text { shelters. This will improve allocation of resources to shelters (such as food } \\
\text { and water), as well as the reunion of separated family members. Such a } \\
\text { system must complement other systems to register evacuees for available } \\
\text { social services. }\end{array}$ \\
\hline $\begin{array}{l}\text { DHS should review and revise } \\
\text { the Federal regulations under the } \\
\text { Stafford Act to emphasize } \\
\text { "location-independent" housing } \\
\text { assistance. }\end{array}$ & $\begin{array}{l}\text { Current regulations allow payment of rental subsidies to disaster victims, } \\
\text { but not the routine payment of security deposits or utility fees. } \\
\text { Reimbursement for repairs to existing available housing units are also not } \\
\text { authorized, effectively precluding the use of a large supply of federally } \\
\text { controlled units that may only need minor repairs in order to be occupied. } \\
\text { These restrictions push people to trailers and other manufactured housing } \\
\text { units, while leaving other available housing vacant. }\end{array}$ \\
\hline
\end{tabular}

\subsection{Congressional recommendations}

Congress convened a special committee after Hurricane Katrina, The United States House Select Bipartisan Committee to Investigate the Preparation for and Response to Hurricane Katrina, which conducted investigations simultaneously while the White House task force completed their work. The committee was charged with conducting "a full and complete investigation and study and to report its findings to the House not later than February 15, 2006, regarding: (1) the development, coordination, and execution by local, State, and Federal authorities of emergency response plans and other activities in preparation for Hurricane Katrina; and (2) the local, State, and Federal government response to Hurricane Katrina" [2]. The investigation included nine hearings, interviews and briefings, and the review of more than 500,000 pages of documents. They issued a final report on February 15, 2006: A Failure of Initiative. The House resolution that chartered the Select Committee charged them with the task of investigating and reporting findings, so the report did not offer specific policy recommendations. However, the conclusion of the report notes that the information in the report should inform legislative, organizational, and policy changes. The key findings related to emergency shelter and housing policy are presented in Table 2.

Table 2: Congressional Committee findings. (Source: The US House Select Bipartisan Committee to Investigate the Preparation for and Response to Hurricane Katrina, 2005.)

Relocation plans did not adequately provide for shelter. Housing plans were haphazard and inadequate.

There was inappropriate delay in getting people out of shelters and into temporary housing - delays that officials should have foreseen due to manufacturing limitations (of trailers)

FEMA failed to take advantage of the Department of Housing and Urban Development's expertise in large-scale housing challenges.

State and local governments made inappropriate selections of shelters of last resort. The lack of a regional database of shelters contributed to an inefficient and ineffective evacuation and sheltering process.

Long-standing weaknesses and the magnitude of the disaster overwhelmed FEMA's ability to provide emergency shelter and temporary housing. 


\subsection{PKEMRA Act of 2006 emergency shelter and housing provisions}

The Post Katrina Emergency Management Reform Act was signed into law on October 4, 2006. This legislation enacts the primary policy changes and governmental agency reforms, and significantly reorganizes FEMA. Several sections of the Act address emergency shelter and temporary housing after disasters. PKEMRA makes several amendments about housing assistance to the Stafford Act, which was the initial legislation that created the disaster framework in place for federal disaster response. The amendments expand FEMA's authority to provide housing assistance to people affected by disaster. One of the challenges with the emergency shelters after Katrina was that families were separated from each other and dispersed across various shelters, and there was no database to track who was in each shelter, so no way to for FEMA to help reunite families. PKEMRA changes this by creating a National Emergency Family Registry and Locator System and Child Locator Center. This is a voluntary family registry and locator system established by FEMA, in collaboration with the Department of Justice, the National Center for Missing and Exploited Children, the Department of Health and Human Services (HHS), and the American Red Cross.

The act also establishes a new housing delivery initiative, the Individuals and Households Pilot Program. The program authorizes the use of existing rental housing to provide temporary housing for those affected by disasters, and authorizes a plan to repair and improve multi-family rental properties so that they can quickly increase rental stock in affected areas. In addition, the Act adds a clause to the Stafford Act to include federal assistance for individuals and households that includes the cost of utilities (except telephones), and security deposits.

The most significant housing policy change is the directive to develop a National Housing Strategy, distinct from the overall recovery strategy section of the legislation. This strategy for housing planning and development includes advocates for the disabled, and address housing challenges for populations with special needs and low-income housing needs. The strategy calls for a review of housing resources and inventory of housing resources available to displaced populations. The Act requires the strategy plan to "outline the most efficient and cost effective Federal programs that will best meet the short-term and long-term housing needs of individuals and households affected by a major disaster; clearly define the role, programs, authorities, and responsibilities of each entity in providing housing assistance in the event of a major disaster" [10]. The strategy emphasizes the role of interagency cooperation and coordination, and a significant role for HUD.

\subsection{Discussion}

The White House report and the congressional committee report have similar recommendations and findings about emergency shelter and housing plans. Both note that the FEMA did not work with HUD, which has important expertise in securing housing. Both reports highlight the need for regional databases of shelters, with the White House report also noting the need for accurate and updated information about people in shelters. The congressional committee report laments that housing plans were haphazard and incomplete. Similarly, the White House report includes specific recommendations to address this failure, by increasing the coordination efforts between the American Red Cross and other agencies like HUD.

The congressional report addresses what they term "long standing weaknesses" with FEMA's ability to provide emergency shelter and temporary housing, and with coordination with the state and local emergency management agencies. The report describes this in more detail, noting that: "Within a month, 44 states had played a role in sheltering the evacuees 
from Hurricanes Katrina and Rita. But it is clear state and local governments in the areas most affected by the hurricanes were not adequately prepared. They failed to learn important lessons from the Hurricane Pam exercise, and lacked the necessary information about temporary housing. Shelters of last resort, designed for people to take refuge in the immediate hours before and after landfall (such as the Superdome), were not of sufficient capacity. Instead, the Superdome, itself located in a floodplain, had to bear a burden for which it was not prepared. The New Orleans Convention Center, never planned as a shelter, became one out of sheer necessity and improvisation. There was no comprehensive database of available shelters, which only complicated relief efforts. There were also delays in getting people out of shelters and into temporary housing. And FEMA's strategy of ordering 200,000 trailers and mobile homes shortly after the storm was blind to the nation's manufacturing capacity of 6,000 units per month" [2, p. 311].

The PKEMRA Act addresses the "long term weaknesses" identified by the congressional committee through the creation of the National Housing Strategy. This is a comprehensive approach to housing, involving multiple agencies and stakeholders, and includes special consideration for vulnerable populations (i.e. disabled, special needs, and low-income residents in affected areas). The comprehensive approach is intended to overcome the delays in meeting emergency and temporary housing needs, as well as the long-standing weaknesses. The Act also incorporates changes to combat the problem of state and local governments choosing inappropriate shelters of last resort by creating the National Housing Strategy and involving all agencies and stakeholders in the planning process.

In addition to the long-term weaknesses that the congressional report identifies, the PKEMRA Act addresses the specific recommendations from the executive investigations. The White House report's recommendation that DHS should develop a system to maintain awareness of the movement of shelter and temporary housing residents, and help with the reunification of families by creating a National Emergency Family Registry and Locator System and Child Locator Center. Likewise, the Individuals and Households Pilot Program addresses the findings in the congressional report that there was an inappropriate delay in getting people out of shelters and into temporary housing. The White House recommendation that DHS should review and revise the Federal regulations under the Stafford Act to emphasize "location-independent" housing assistance is addressed by the amendments to the Stafford Act that establish the Individuals and Households Pilot Program. The changes that allow federal assistance in security deposits and paying for utilities is a policy to help move disaster victims out of emergency housing shelters into more permanent housing. PKEMRA Act elevates the role of HUD. While the act does not specify that HUD would take the lead in housing as the report recommended, HUD is elevated to a full partner along with other agencies who can offer support for disaster victims. As the White House report recommends, ARC (American Red Cross) and DHS (Department of Homeland Security) retain the mass care and sheltering responsibility during disasters.

In sum, all of the recommendations and failures identified in the investigations by the executive and congressional branches were incorporated into legislative policy changes, as outlined in the PKEMRA Act of 2006. The Act completely overhauled FEMA and the emergency management policies and procedures in response to the failures identified in the preparation for and response to Hurricane Katrina.

\section{CONCLUSION}

The results of this study suggest that the "lessons learned" narrative is appropriate in this case. The recommendations and findings of the investigations conducted by the executive and congressional branches were incorporated into legislative changes. Thus, we conclude 
that policy learning occurred in the wake of disaster. These results are limited in scope, examining only emergency shelter and housing policy, and only Hurricane Katrina, an event that is exceptional in scope and scale. However, emergency shelter and housing policy is an area that is essential in disaster response. This study is encouraging from a normative perspective, as society hopes that our governmental leaders learn lessons after disasters that inform policy decisions and create improvements for future disaster management. This study is part of an ongoing research project, which will expand the scope to investigate other policy domains, and all of the post-Katrina policy reforms and changes.

\section{ACKNOWLEDGEMENT}

The author thanks McKenzie Meade for research assistance on this project.

\section{REFERENCES}

[1] Bush, G.W., The Federal Response to Hurricane Katrina: Lessons Learned, The White House, President, Online. https://georgewbush-whitehouse.archives.gov/reports/ katrina-lessons-learned/index.html. Accessed on: 15 May 2017.

[2] A Failure of Initiative: Final Report of the Select Bipartisan Committee to Investigate the Preparation for and Response to Hurricane Katrina, Online. https://www.gpo.gov/fdsys/pkg/CRPT-109hrpt377/pdf/CRPT-109hrpt377.pdf. Accessed on 15 May 2017.

[3] Birkland, T.A., Lessons of Disaster: Policy Change After Catastrophic Events, Georgetown University Press: Washington, DC, 2006.

[4] Kingdon, J.W., Agendas, Alternatives, and Public Policies, Pearson Education Limited, 1995.

[5] Baumgartner, F.R. \& Jones, B.D., Agendas and Instabilities in American Politics, The University of Chicago Press: Chicago and London, 1993.

[6] Stone, D., Policy Paradox, W.W. Norton \& Company, 2001.

[7] Birkland, T.A., After Disaster: Agenda Setting, Public Policy, and Focusing Events, Georgetown University Press: Washington, DC, 1997.

[8] Kurtz, R.S., Coastal oil pollution: spills, crisis, and policy change. Review of Policy Research, 21(2), pp. 201-219, 2004.

[9] May, P.J., Policy learning and policy failure. Journal of Public Policy, 12(4), pp. 331354, 1992.

[10] The Post Katrina Emergency Management Reform Act of 2006, Online, www.doi.gov/sites/doi.gov/files/uploads/Post_Katrina_Emergency_Management_ Reform_Act_pdf, Accessed May 16, 2017. 